\title{
Characterization of Field Concrete
}

\section{Paul E. Stutzman}

U.S. DEPARTMENT OF COMMERCE Natlonal Instltute of Standards and Technology Bullding and Flre Research Laboratory Galthersburg, MD 20899 



\section{Characterization of Field Concrete}

Paul E. Stutzman

U.S. DEPARTMENT OF COMMERCE Natlonal Institute of Standards and Technology Bullding and Fre Research Laboratory Galthersburg, MD 20899

January 1991

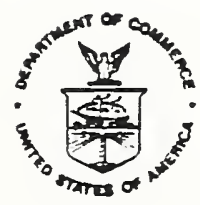

U.S. DEPARTMENT OF COMMERCE Robert A Mosbacher, Secrotary NATIONAL INSTITUTE OF STANDAROS AND TECHNOLOGY John W. Lyons, Director 



\section{ABSTRACT}

Field inspection and laboratory analysis of concrete and concrete structures are necessary for condition evaluation, determination of the need and extent of repairs, and for the prediction of concrete service life. A detailed evaluation includes field inspection, field testing, sampling, and laboratory analyses and also involves the description of the structure, concrete, and aggregates. Field inspection for overall structure condition includes the identification and description of surface defects, cracks, and cracking patterns. Field testing determines relative concrete quality and location of degraded concrete, and provides guidance in developing a sampling plan. Laboratory analyses provide detailed information on the microstructure, phase composition, chemical composition, and strength of the concrete.

This report discusses the inspection and evaluation of field concrete, the application of field tests for determining concrete condition, sampling concrete for analyses, and laboratory testing for the characterization and evaluation of concrete microstructure.

Key Words: characterization, concrete, evaluation, field survey, field testing, laboratory analysis, microscopy, petrography 

Page

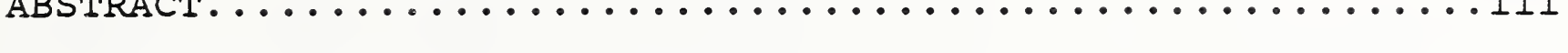

IIST OF FIGURES ............................... v

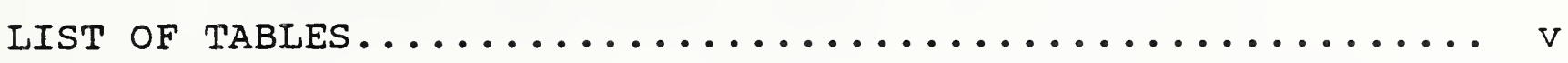

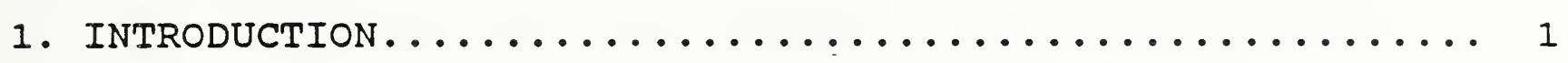

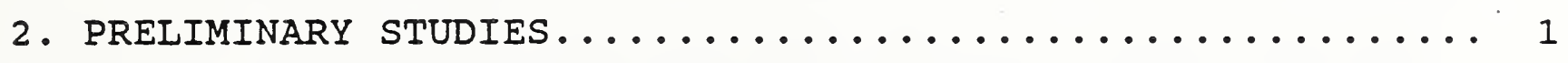

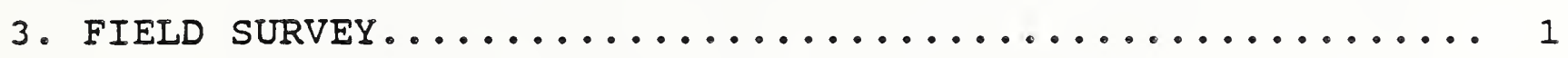

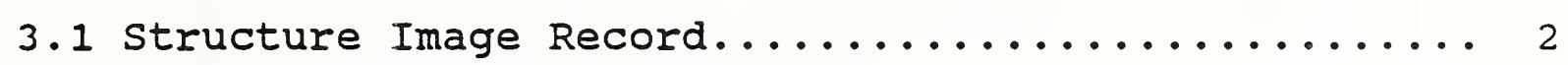

3.2 Surface Defects............................ 4

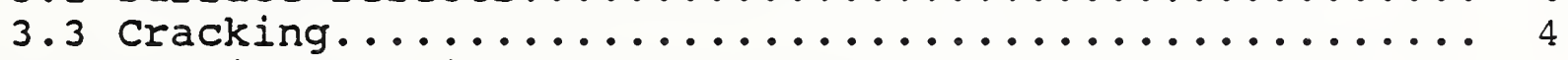

3.4 on-site Testing............................ 5

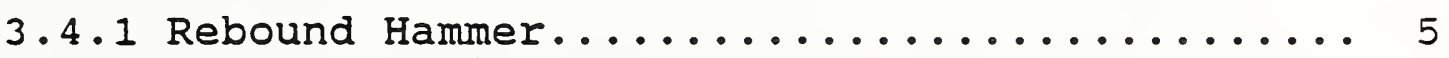

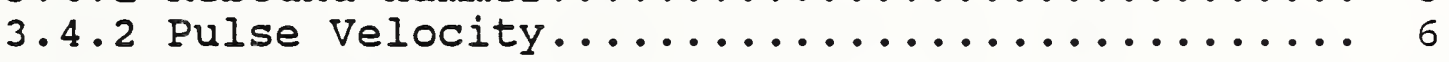

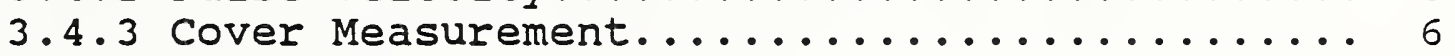

3.4.4 Penetration Resistance.................. 6

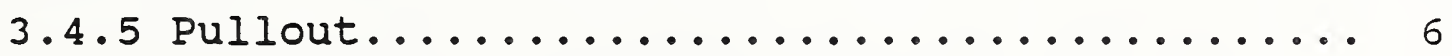

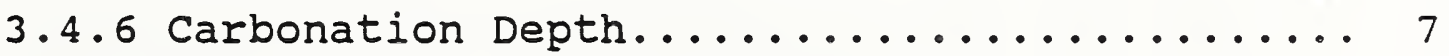

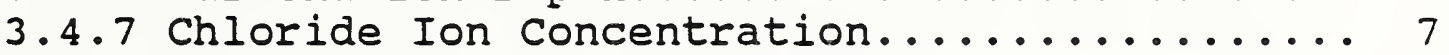

$3.4 .8 \mathrm{Half}-\mathrm{Cell}$ Test for corrosion.............. 7

3.4 .9 Alkali-Aggregate Reaction............... 8

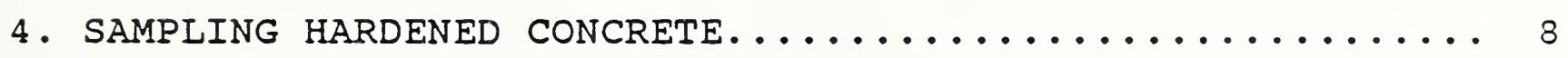

5. IABORATORY ANALYSIS OF HARDENED CONCRETE............... 9

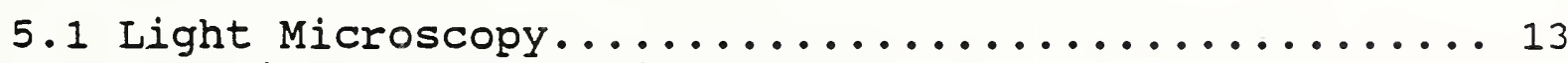

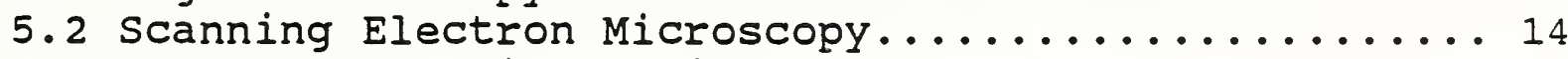

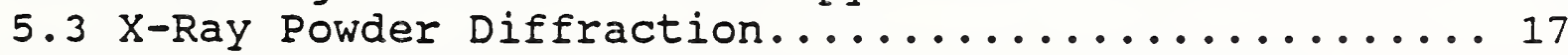

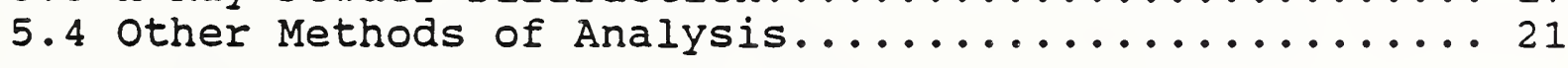

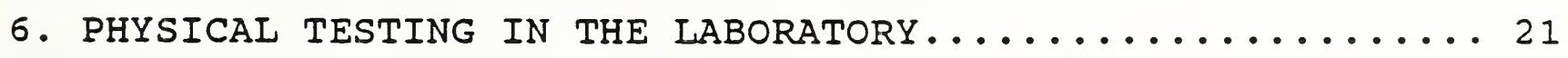

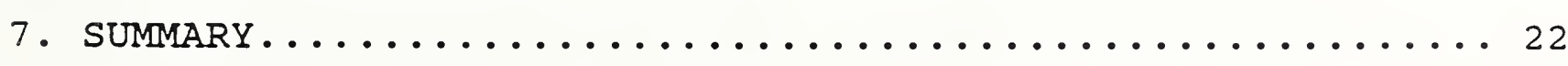

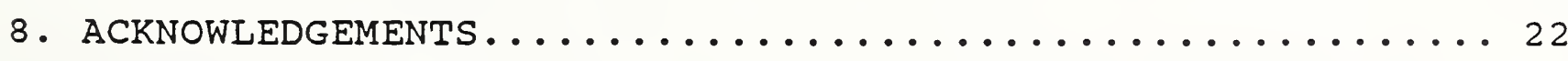

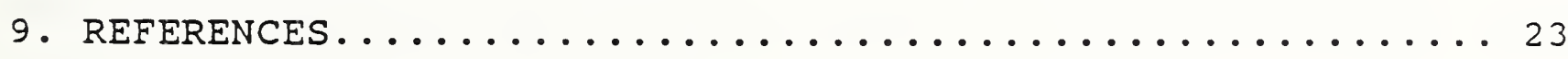


- 
Figure 1. Crack types and origins, from [11]......... 5

Figure 2. Ontario Ministry of Transportation petrographic analysis data sheet, page 1 of $2 \ldots \ldots \ldots \ldots \ldots 11$

Figure 3. Ontario Ministry of Transportation petrographic analysis data sheet, page 2 of $2 \ldots \ldots \ldots \ldots \ldots 12$

Figure 4. Secondary electron image (a) of a fresh fracture surface showing calcium hydroxide $(\mathrm{CH})$, calciumsilicate-hydrate ( $\mathrm{CSH}$ ), and void space (V), and (b) energy dispersive $\mathrm{X}$-ray spectrum of calcium hydroxide; peaks indicate the presence of calcium $(C A)$ and oxygen $(0) \ldots \ldots \ldots \ldots \ldots \ldots \ldots$

Figure 5. Backscattered electron images of (a) hardened concrete and (b) hardened cement paste with aggregate (A), anhydrous cement (AC), hydrated cement paste (HCP), calcium hydroxide (CH),

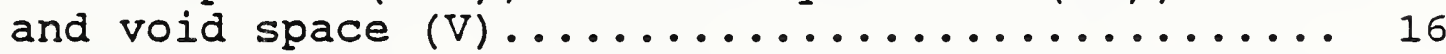

Figure 6. X-ray powder diffraction pattern of hydrated cement paste (a) and carbonated paste (b) with calcium hydroxide ( $\mathrm{CH}$ ), ettringite (E), calcite

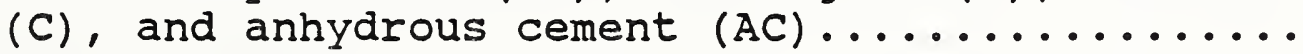

\section{LIST OF TABLES}

Table 1. List of Items for a Field Survey, modified

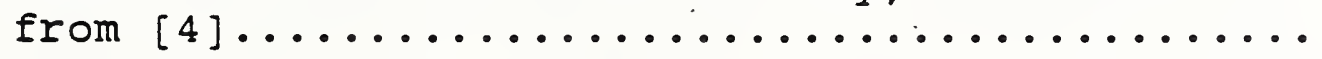

Table 2. Outline of Recommended Information for a Survey and Sampling of Field concrete from 1,3,4, and 7.3

Table 3. Core and test cylinder log from the Bureau of Reclamation [35] and a suggested list of details

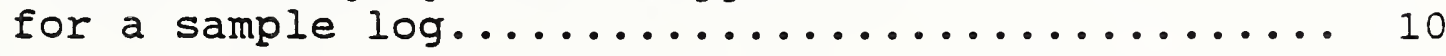

Table 4. Sample Preparation for X-Ray Powder Diffraction

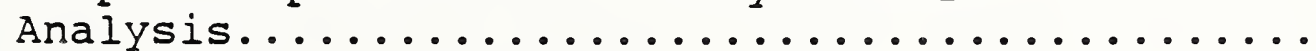

Table 5. Key X-ray Powder Diffraction Lines for Hydrous and Anhydrous Cement Compounds, From Mather [57].... 19 
$-$ 


\subsection{INTRODUCTION}

Field inspections are conducted on concrete to determine its condition, to evaluate its performance, and to determine if repairs or replacement are necessary. Field evaluation provides information on conformance of the concrete to construction specifications, condition and uniformity assessment of the concrete, and the identification of service conditions and processes which may affect the concrete performance. Information derived from the inspection and testing includes estimates of the remaining service life, performance of materials or components used in the concrete, and the best methods and materials for repair $[1,2]$.

A complete study of a structure is ideally composed of three parts: a) preliminary studies to obtain information on the original specifications, construction history, and working history of the structure; b) field inspection, including environmental exposure assessment, concrete evaluation, and sampling; and c) laboratory studies for in-depth analysis of the condition of the material.

Many tools and test procedures are available to examine field concrete and much of the evaluation can be performed in the field by visual, nondestructive, and simple chemical test procedures. However, the laboratory provides many useful analytical tests ranging from the macro- to micro- analytical scales to characterize cement and concrete microstructure.

\subsection{PRELIMINARY STUDIES}

Compilation of the construction specifications, plans, construction reports, cement and aggregate specifications and test data, concrete mixture proportions, and concrete quality control test data will provide the investigator with valuable information on the original concrete mix, materials, and of any field changes made during construction. Information on service conditions and on previous in-service inspections should be considered in order to plan the field investigation $[3,4,5,6]$.

\subsection{FIELD SURVEY}

A list of suggested items needed for making a field survey is given in Table 1. Table 2, listing information which should be obtained in a field survey, has been compiled from inspection guidelines for concrete structures $[1,3,4,7]$. Field inspection of a structure provides the opportunity to document the condition of the structure, to identify, describe, and quantify the extent of the damage or distress, and to describe the environment and service conditions. Structure condition records can be obtained by either photography or sketches. Field tests are conducted to make preliminary analyses which then can be used in sampling the concrete for further laboratory study. 
Table 1. List of Items for a Field survey, modified from [4].
a) Structure drawings, if available.
b) Hand lens or pocket comparator, 10 to $15 \mathrm{x}$ magnification.
c) Clipboard and paper or field book, pencils, sharpener.
d) Tape measure, 15 to $30 \mathrm{~m}$., (50 to $100 \mathrm{ft.}$ ).
e) Graduated ruler.
f) Feeler gage.
g) Knife.
h) Rock hammer.
i) Fine wire (not too flexible).
j) string.
k) Flashlight or lantern.
1) Camera $\mathrm{w} / \mathrm{flash}$ and macro lens.
m) Scales for photographs (feet, meters, inches, millimeters).
n) Assortment of film - color and black and white.
o) Sample bags, felt tip labelling pens, labels, masking tape

Obvious indicators of potentially degraded concrete are surface defects, cracks, exudations, and precipitates or efflorescence. Location of degraded or substandard concrete not exhibiting any outward signs of the distress may require field testing followed by sampling and laboratory analyses. There are many processes that are potentially damaging to concrete and they manifest themselves in different ways. The damage observed in the field is sometimes the result of more than one of these processes, complicating the analyses and evaluation [2].

\subsection{Structure Image Record}

Detailed photographs or sketches of the structure will serve as a record of its condition at the time of inspection, and as a reference with which to compare future surveys. A small tape recorder is a useful alternative to a field notebook. Drawings with notes on the type, location, and extent of damage to the concrete are valuable. A $35 \mathrm{~mm}$ camera with macro, wide angle and telephoto lenses will be able to record general images as well as close-ups for detail photography. A flash attachment may be necessary for poorly lit areas. A scale, preferably a ruler, should be included in each close-up photograph. Images for computer image analysis should be shot perpendicular to the concrete surface to minimize the image distortion created by photographing at an oblique angle. Color photographs are acceptable for reports, but black and white images may provide the best feature contrasts for image analysis. 
Table 2. Outline of Recommended Information for a Survey and Sampling of Field Concrete from $1,3,4$, and 7 .

STRUCTURE IDENTIFICATION:

STRUCTURE LOCATION:

STRUCTURE DESCRIPTION:

TYPE OF CONSTRUCTION:

INSPECTION DATE:

AGE OF STRUCTURE:

CONCRETE TYPE: mass, reinforced, prestressed

LOCATION ENVIRONMENT: region, topography

LOCATION EXPOSURE CONDITIONS:

mean annual temperature, temperature ranges, annual rainfall, humidity, pressure, freeze/thaw cycles, water immersion, tide exposure, sea water, ground water, soft water, de-icing salt, type of contact, concentration of aggressive substances, frequency and duration of exposure, wear, overloading, and special environmental influences (e.g. stray electrical currents)

OVERALL CONCRETE OUALITY:

Hammer Test:

Concrete Friability: Ring/Dull

Concrete Friability: powdery, well cemented

Cement/Aggregate Bond: Good/Bad

Unusually Wet/Dry Areas: Yes/No

SURFACE FEATURES/DEFECTS:

Honeycomb, air surface voids, form-streaking

subsidence cracking, color variation

sand streaking, layer lines

form offsets, cold joints

CRACKING SURVEY:

Crack type, width, direction, abundance, location

Features associated with cracking (i.e. efflorescence, exudations, carbonation, spalling, offsets)

EMBEDDED ITEMS:

Description:

Location:

Condition: clean, corroded, decayed, associated voids, cracks, mineralization

CONCLUSIONS:

SAMPLING LOCATION RECOMMENDATIONS: 


\subsection{Surface Defects}

Important surface defects defined and illustrated in the American concrete Institute (ACI) report 309.2R [8] are: 1) honeycomb; 2) surface air voids; 3) form streaking; 4) subsidence cracking; 5) color variation; 6) sand streaking; 7) layer lines; 8) form offsets; and 9) cold joints. Other defects that should be documented on the evaluation form include spalling, scaling, popouts, exudations, seepage, and erosion. These defects are generally the result of poor selection of materials, inadequate design or construction practices, poor consolidation, or severe weather conditions [8].

\subsection{Cracking}

Cracking may range from very fine microcracking not discernible by eye to large cracks with widths measured in millimeters. Cracks may or may not pose a structural problem, but may provide a zone of relatively high permeability providing access to the interior for damaging agents [9].

Non-structural cracking in concrete can generally be classified into two categories; a) cracking of unhardened concrete, and b) cracking of hardened concrete (figure 1). Causes of these cracks include shrinkage, freezing damage, cement-aggregate reactions, and corrosion of reinforcement. A cracking survey of a structure should identify the type, location, and extent of cracking.

Reports on the description, identification, and classification of cracks and possible causes of cracking, which will aid in making crack surveys, are available $[3,7,10,11,12]$. The use of image processing and analysis for crack identification and determination of the cause of cracking by using an expert system is described by Kaetzel et al. [13].

The crack survey portion of the field survey form (Table 2) gives suggestions for the characterization of cracks. Cracks are described by: a) crack type; b) crack width; c) direction; d) depth; e) pathways around or through the aggregate, f) any crackfilling material; $g$ ) other damage such as spalling, surface deterioration, rust staining; and $h$ ) any association with embedded items such as reinforcement or contaminants. 


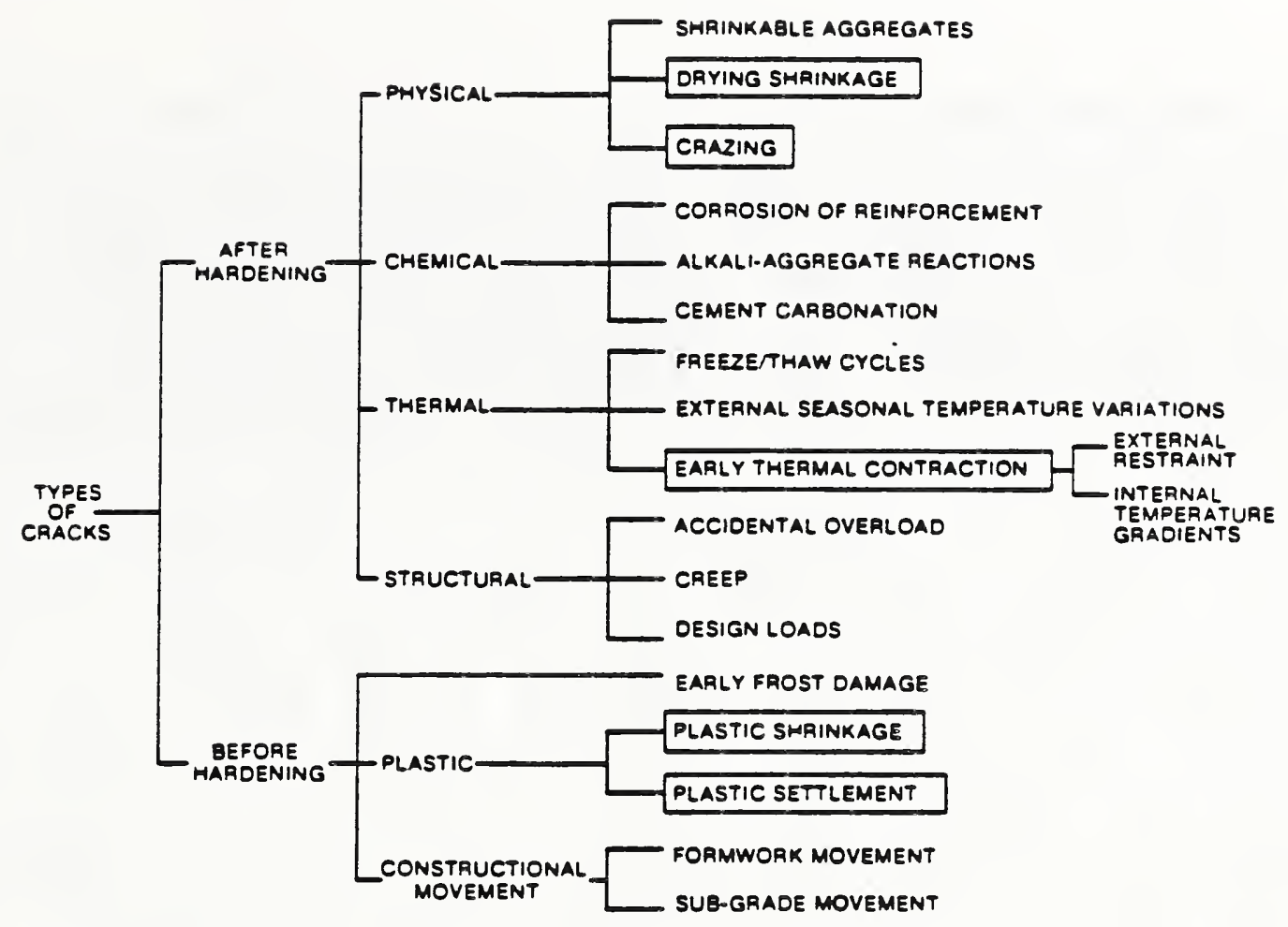

Figure 1. Crack types and origins from [11].

\subsection{On-Site Testing}

Bungey [14], Mathey and Clifton [15], Mather [16], Brink [17], and Malhotra and Carino [18] present reviews of physical methods for field testing concrete. Field test methods are classified into three general categories: non-destructive, partially destructive, and destructive tests. Non-destructive test procedures will not damage the concrete. Partially destructive tests may produce minor surface damage which is easily repaired. Destructive tests permanently alter the member or sample extracted from the member. A simple non-destructive field test involves tapping the concrete with a hammer to assess the relative condition of the concrete. A sharp ring is characteristic of sound concrete, while a dull thud indicates cracking, delamination, or other problems.

\subsubsection{Rebound Hammer}

The rebound hammer is a non-destructive test procedure where a spring-driven steel hammer is impacted with a fixed, reproducible velocity against a steel plunger in contact with the concrete surface. The rebound distance of the hammer is read off a scale on the tool and is a measure of the relative hardness of the concrete surface [14,18]. ASTM C 805 [19] has been developed as a standard test for determining rebound number. Many factors such as cement type, cement content, coarse aggregate type, concrete age, curing methods, degree of carbonation, moisture, and surface condition can affect the results, therefore strength estimations are unreliable. However, this method is useful for rapid assessment of the uniformity of concrete over large regions and for location of deteriorated or sub-standard concrete [14]. 


\subsubsection{Pulse Velocity}

The pulse velocity test is non-destructive and may be used to determine the presence of cracks, voids, crack depth, and general quality of the concrete. ASTM C 597 [20] has been developed as a standard test method for determination of pulse velocity. A pulsed compressional wave passed through the concrete is delayed by the presence of cracks and voids in concrete, making this test useful for assessment of concrete uniformity and relative condition. With a separate wave source and detector, pulse velocity tests can be performed on flat surfaces and around corners, but the best test configuration has the source and detector opposite each other as in testing a beam. Pulse velocity measurements are affected by the quality of source and detector contact with the concrete, temperature extremes, moisture, and the presence and orientation of reinforcement steel. For example, the pulse-velocity wave travel time is shorter when measured parallel to the steel than when measured perpendicular to the reinforcing steel $[14,20]$. Operator skill is necessary for interpretation of the pulse-velocity test data.

\subsubsection{Cover Measurement}

The thickness of concrete over reinforcement serves as a protective barrier. Location of reinforcement and determination of concrete thickness can be done with a covermeter $[14,15]$. Measurement of the disturbance of a magnetic field is used to locate the reinforcement. If the reinforcement bar size is known, the degree of disturbance can be used to estimate the depth of cover. The covermeter is also used to locate reinforcement-free regions for coring.

\subsubsection{Penetration Resistance}

This partially destructive procedure has been standardized in ASTM C 803 [21] and involves the firing of a steel bolt or pin into the concrete. The penetration depth of the bolt or pin can be related to relative concrete quality and uniformity. Calibrations relating penetration depth to strength can be used for estimation of concrete strength. Calibrations may be affected by factors like field concrete curing and environment conditions, aggregate type and content, and concrete strength. Correlation of penetration resistance with core strengths are necessary for reliable estimates [21].

\section{4 .5 Pullout}

The partially destructive pullout test is commonly used during construction to determine if the concrete has attained sufficient strength for work to proceed. A bolt with an enlarged head cast in the concrete is pulled out, and the force required to pull the bolt is related to concrete strength. The method has been 
standardized in ASTM C 900 [22]. This test is primarily a surface test, but derives the information from a greater depth than the rebound hammer method. The relationship of pull-out force to concrete strength requires calibration by preparing test specimens with similar materials and under similar curing conditions as the field concrete $[14,22]$. Methods have been developed to perform this test by drilling into hardened concrete and inserting expanding devices which are pulled out. However, these have not been standardized.

\subsubsection{Carbonation Depth}

RILEM recommendation CPC-18 [23] on Measurement of Hardened Concrete Carbonation Depth and Parrott [24] use phenolphthalein indicator solution to locate regions of carbonated concrete. Phenolphthalein indicator is a solution of $1 \%$ phenolphthalein in 70\% ethyl alcohol. The spray-applied indicator turns a bright magenta where the concrete has a pH of 9 or greater, indicating non-carbonated concrete, while remaining colorless in carbonated concrete. Clean fresh-fractured surfaces, fresh-drilled powders, and fresh-sawn surfaces are suitable for testing. Depth measurements are reported to the nearest millimeter. Maximum and minimum carbonation depths should also be recorded.

\subsubsection{Chloride Ion Concentration}

The presence of chloride ions in concrete can cause accelerated corrosion of reinforcing steel [9]. Field test kits for measurement of chloride ion concentration and chloride ion ranges are in use $[14,25,26]$. Jang and Iwasaki [27] have developed a color indicator method for the visual identification of chloride distribution. AASHTO T 260-84 [28], Standard Method of Sampling and Testing for Total Chloride Ion in Concrete and Concrete Raw Materials is a laboratory procedure for the determination of either the water-soluble chloride or total chloride content in a field sample.

\subsubsection{Half-Cell Test for Corrosion}

ASTM C 876 [29], Standard Test Method for Half-Cell Potentials of Uncoated Reinforcing steel in Concrete, is used to evaluate the corrosion potential of the reinforcement. One electrode of $a$ copper-copper sulfate half-cell is connected with a voltmeter to an exposed portion of the reinforcing steel. The half-cell is placed at various locations on the concrete while recording the potential of the reinforcement. The data are plotted in the form of an equipotential contour map with high readings indicating areas of possible reinforcement corrosion, intermediate readings indicating the possible development of corrosive conditions, and low readings for regions where the steel is not corroding [14]. 


\subsubsection{Alkali-Aggregate Reaction}

Two procedures for identifying alkali-aggregate reaction having potential as field tests have been described by Natesaiyer and Hover [30,31], Natesaiyer et al. [32], and Poole et al. [33]. These tests are staining or marking procedures where the alkalisilica gel is marked in the former procedure by the adsorption of uranyl ions and in the latter by the absorption of copper ions. The ultra-violet light fluorescence of the uranyl ions and the blue color of the copper ions highlight the regions of alkalisilica gel. The strategic Highway Research Program (SHRP) has produced a handbook for identification of alkali-silica reaction (ASR) in field concrete with photographs of ASR in pavements and bridge structures, guidelines for identification of ASR gel in core, polished slabs, and hand specimens, and an illustration of the uranyl ion fluorescence field identification procedure [34].

These field tests serve to identify substandard concrete and to establish the extent of the damaged regions. Samples of the field concrete need to be collected and laboratory analyses, detailed petrographic, and chemical tests are necessary to characterize and evaluate the interior of the concrete.

\subsection{SAMPLING HARDENED CONCRETE}

ASTM-C 823 [1] provides guidance for the selection and development of a sampling scheme. ASTM C 42 [35] is a standard method for the collection of samples. General strategies in sampling of hardened concrete include: a) selecting samples that are deemed typical of the construction or region of the construction; b) purposely selecting samples of distressed areas in an effort to identify the cause of degradation and determine the extent of the damage; and, c) a combination of the two schemes.

Bungey [14] suggests that a minimum of two samples be obtained from structures having up to $10 \mathrm{~m}^{3}$ of concrete and also made the following recommendations: a) the minimum sample dimension be at least five times the maximum aggregate size; b) the sample should be in one piece; and $c)$ the sample should be free of reinforcement or foreign matter except where it is to be included in the study.

The U.S. Bureau of Reclamation Concrete Manual [36] recommends diamond core drilling for sample collection because a complete specimen from the surface to depth can be collected with a minimum of damage. Coring provides specimens in size from about 50 to $250 \mathrm{~mm}$ (2 to $10 \mathrm{in}$ ) in diameter with use of a portable drill rig, with the core diameter being at least three times the maximum aggregate diameter. 
Samples should be marked with an indelible marker with the following information: a) sample number; b) collection method; depth; d) location in the structure; e) top and base or outer surface and interior; $f$ ) orientation; and $g$ ) fracturing and lost material due to the coring operation. A brief field description of the concrete noting condition, color, and aggregate distribution, will assist the petrographic analysis. The field log should note the sample collection mode to avoid possible misinterpretations, as concrete collected using a hammer and chisel is likely to crack as a result of sampling. The concrete can then be wrapped in plastic, sealed, and carefully boxed for transportation to the laboratory. A Bureau of Reclamation core and test cylinder $\mathrm{log}$ and suggested details for documentation of samples are given in Table 3 .

\section{O LABORATORY ANALYSIS OF HARDENED CONCRETE}

Analytical laboratory methods include visual inspection, microscopy, X-ray powder diffraction, and chemical analysis. These analytical procedures provide the means to investigate the microstructure, composition, distribution of components, and to evaluate any deterioration on a wide scale range. concrete petrography is the description, classification, and evaluation of hardened concrete for determination of its composition, internal structure, and for the classification by type, condition, and expected performance of concrete [2].

Applicable procedures and tests for the examination of hardened concrete include: Petrographic Examination of Hardened Concrete, ASTM C 856 [37], Microscopical Determination of Air-Void Content and Parameters of the Air-Void system in Hardened concrete ASTM C 457 [38], and for aggregate, Standard Descriptive Nomenclature for Constituents of Natural Mineral Aggregates ASTM C 294 [39], and Petrographic Examination of Aggregates for Concrete ASTM C 295 [40]. An example of the information collected by petrographic examination of hardened concrete is illustrated in figures 2 and 3 , a form used by the ontario Ministry of Transportation. 
Table 3. Core and test cylinder log from the Bureau of Reclamation [36] and a suggested list of details for a sample log.

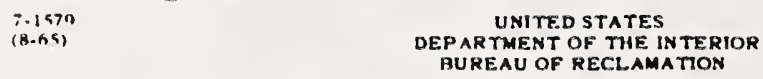

UNITE.D STATES

DEPARTMENT OF THE INTERIOR

BUREAU OF RECLAMATION

COMCRETE CORE DATA SHEET

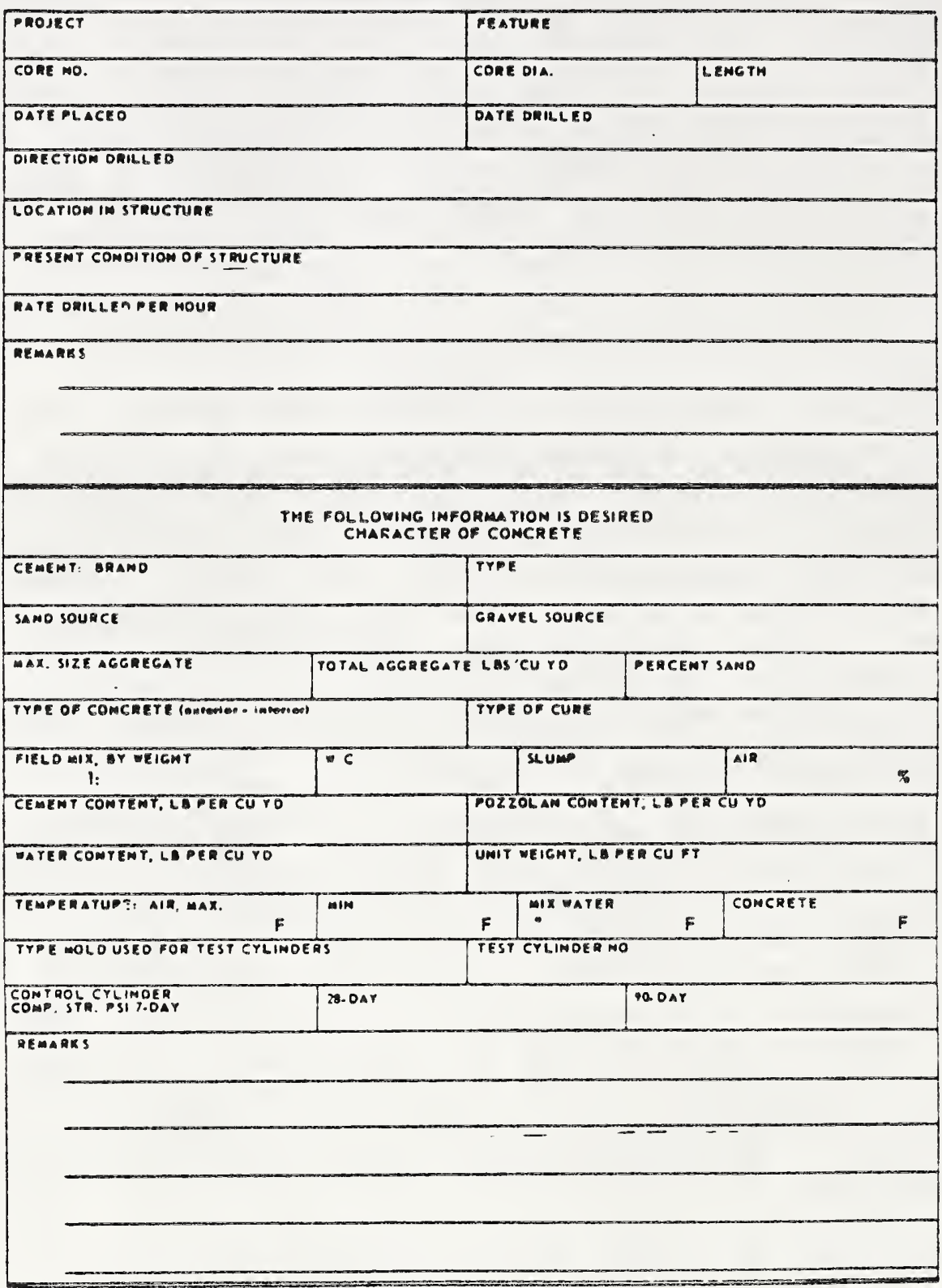

LOG:

Include core location, conditions at surface, depth of obvious deterioration, fractures and conditions on fractured surfaces, unusual deposits, coloring or staining, distribution and size of voids, locations of observed construction joints, contact with foundation or other surfaces, if any.

PHOTOGRAPHIC/SKETCH SURVEY

Identify and photograph any cracking, spalling, scaling, popouts, honeycombing, exudation, distortion, unusual discoloration, erosion, seepage, joints, corrosion of reinforcement. 
0

SAMPLE NO.:

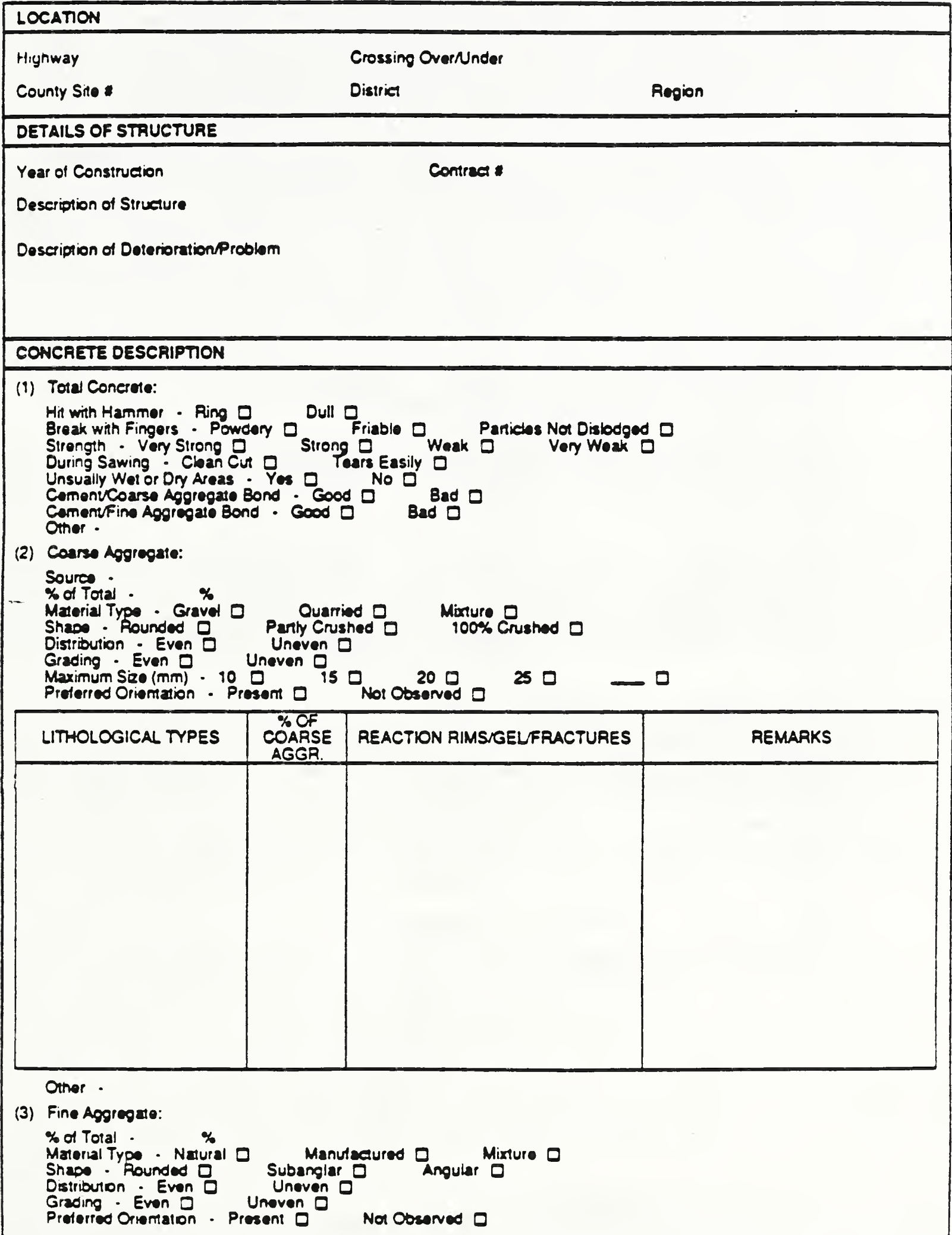

Figure 2. Ontario Ministry of Transportation petrographic analysis data sheet, page 1 of 2 . 


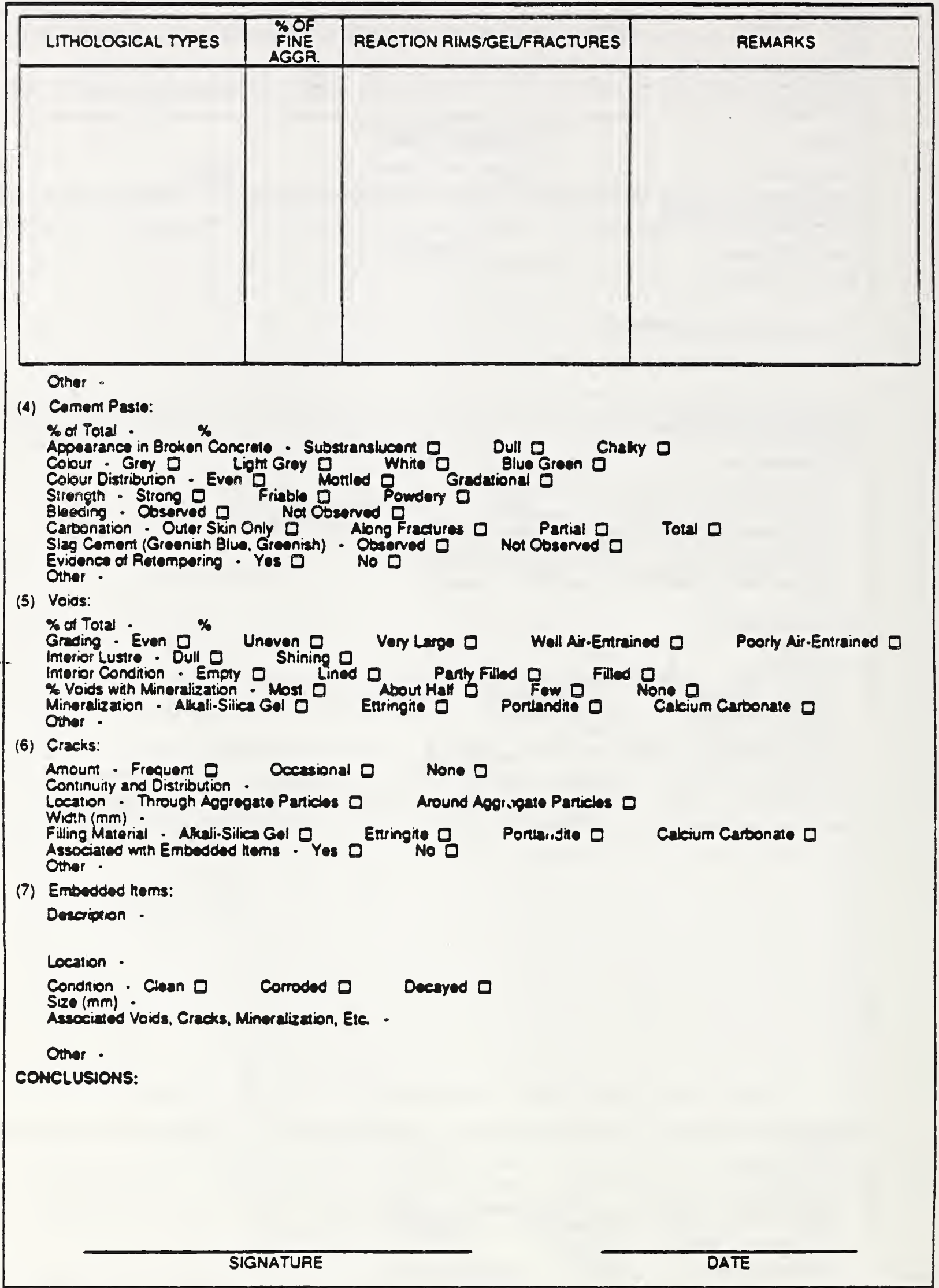

Figure 3. Ontario Ministry of Transportation petrographic analysis data sheet, page 2 of 2 . 


\subsection{Light Microscopy}

Light microscopy has an important role in the evaluation of cement and concrete. Examples of the application of the light microscope in concrete petrography can be found in Brown [41], Campbel1 $[42,43]$, Mather [2], Erlin [44,45], Mielenz [5,46], Idorn [47], Dolar-Mantuani [48], and in ASTM STP 1061 [49].

Three types of light microscopes are commonly used: a) the stereo microscope, for low magnification (10x to 100x) viewing of polished sections and fracture surfaces; b) the polarized light microscope, low to high magnification (50 to $1000 \mathrm{x}$ ) microscopy of thin sections of concrete, mortar, and aggregate and powdered grain mounts for phase identification; and c) the reflected light microscope, for low- to high-magnification imaging of polished sections of concrete and clinker for identification of anhydrous cement phases. Point-counting and linear traverse techniques for quantitative analysis are explained in ASTM C 457 [38].

Polished sections for stereo and reflected light microscopy are prepared by slabbing the sample, lapping, and grinding the surface to a fine luster. A preparation procedure is provided in ASTM C 856 [37]. Thin sections are used for transmitted light microscopy. A polished section of concrete is glued to a glass microscope slide and ground to a thickness of approximately $20 \mu \mathrm{m}$ and examined using a transmitted polarized light (petrographic) microscope. A detailed sample preparation procedure for thin sections is provided by Campbell [43].

The stereo microscope allows low- to medium-magnification viewing of the concrete for examination of the aggregate mineralogy, grading, and distribution, the overall condition of the cement and air void system, cement/aggregate ratios, cracking, identification of some mineral admixtures, degree of hydration, detection and identification of secondary compounds, and general physical properties such as hardness, and relative porosity [44].

Transmitted light microscopy is often used to study cement, concrete, and aggregates. Individual components in the thin section have characteristic optical properties which allow their identification. An analysis may include information on the types, proportions, and distribution of the aggregates, paste compounds, and mineral admixtures [42]. The condition of the paste-aggregate bond, the amount and distribution of porosity and the void system can easily be observed, especially if specimens are impregnated with a colored embedding material or a fluorescent dye [50].

Reflected light microscopy is used to identify unhydrated cement and for clinker analysis. Campbell [43] published a guidebook for reflected light and transmitted light petrography of cement clinker. Reflected light microscopy is not as useful as transmitted light microscopy for concrete analysis because of difficulties in phase discrimination [42]. 


\subsection{Scanning Electron Microscopy}

The application of the scanning electron microscope (SEM) is becoming increasingly popular to characterize cement and concrete $[51,52]$. Images of surface topography, individual phases, and chemical composition from the microscope can be measured and quantified by image analysis. Specimens suitable for SEM analysis include fracture surfaces for surface topography studies and polished sections for phase abundance and distribution studies. Preparation procedures for embedding hardened. cement pastes without drying [53] and polishing techniques [54] have provided well-impregnated, flat surfaces for examination.

Figures 4 and 5 illustrate secondary electron (SE) SEM imaging of surface topography, and backscattered electron (BE) SEM imaging of phase distribution. In figure $4(\mathrm{a})$, a SE image of a freshfracture surface of concrete, hexagonal calcium hydroxide ( $\mathrm{CH}$ ) plates are intermixed with clusters of calcium-silicate-hydrate (C-S-H) needles. Figure $4(\mathrm{~b})$, an energy dispersive $X-r a y$ spectrum of $\mathrm{CH}$, shows it is composed of calcium and oxygen. Figure 5 (a) is a low-magnification BE image of an epoxyimpregnated, polished section of hardened concrete. In BE imaging, the bright grains are unhydrated cement, the intermediate gray matrix is the hydrated cement paste, the dark gray particles are sand, and the black regions are epoxy-filled void spaces. Figure $5(\mathrm{~b})$ illustrates higher-magnification $B E$ imaging of the cement paste. Porous $\mathrm{C}-\mathrm{S}-\mathrm{H}$ comprises the bulk of the paste with bright anhydrous cement grains rimmed with a intermediate gray calcium-silicate-hydrate, and the light gray calcium hydroxide appearing elongated in cross section. Using image analysis, the backscattered electron image can be processed to isolate and determine the area fractions of the individual phases.

Another technique commonly employed in electron microscopy is chemical X-ray microanalysis. X-rays are produced as a result of the interaction of the electron beam with the sample. When an inner atomic shell electron ejected by the incident electron beam an outer atomic shell electron fills the vacancy emitting an $x-$ ray with an energy level characteristic of the difference in energy states and of that element. The X-rays are detected and analyzed by measuring either their wavelength or energy, with both qualitative and quantitative analyses possible [55]. As previously noted, figure $4(\mathrm{~b})$, an $\mathrm{X}$-ray spectra of calcium hydroxide, reveals that the material is composed of calcium and oxygen. 


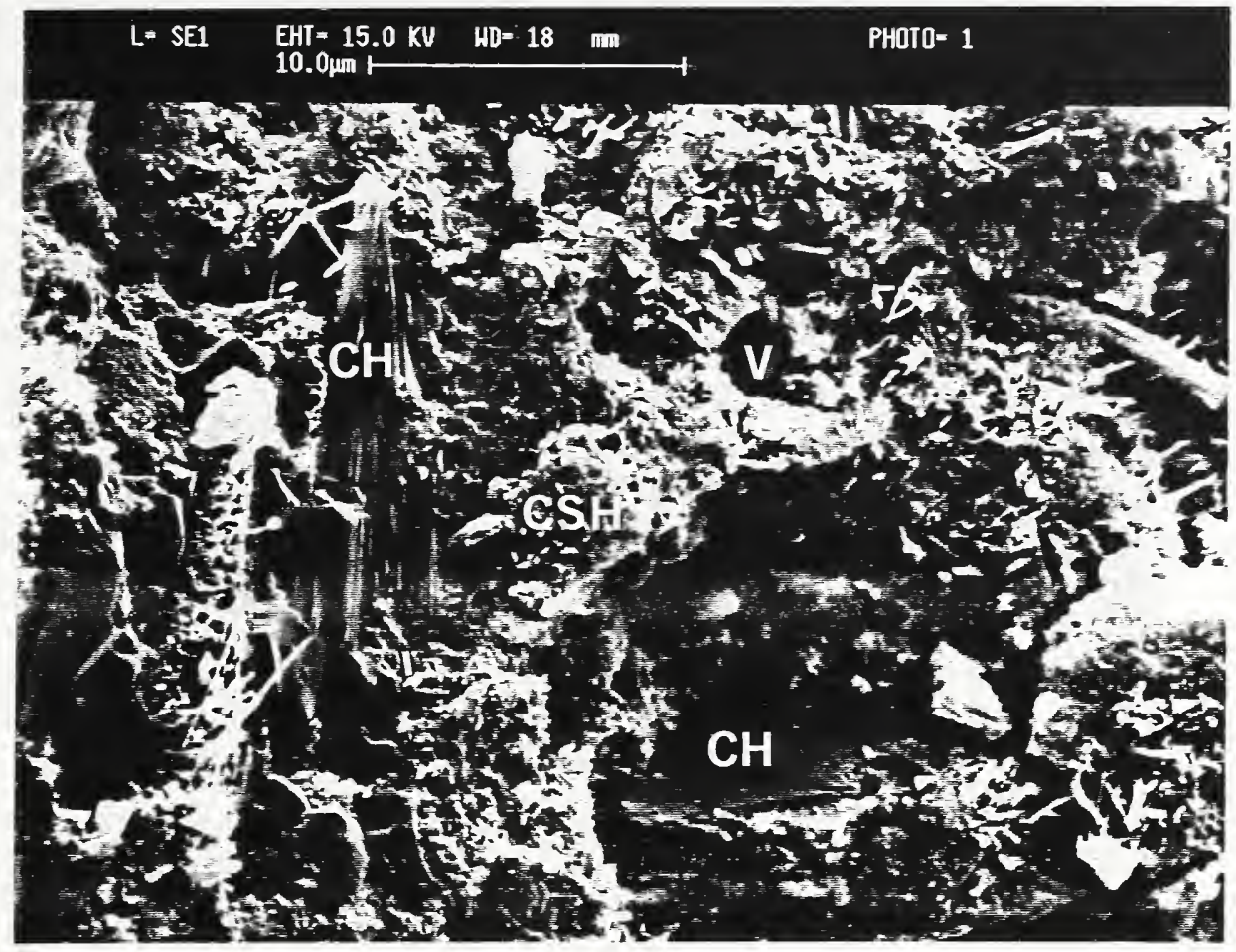

(a)

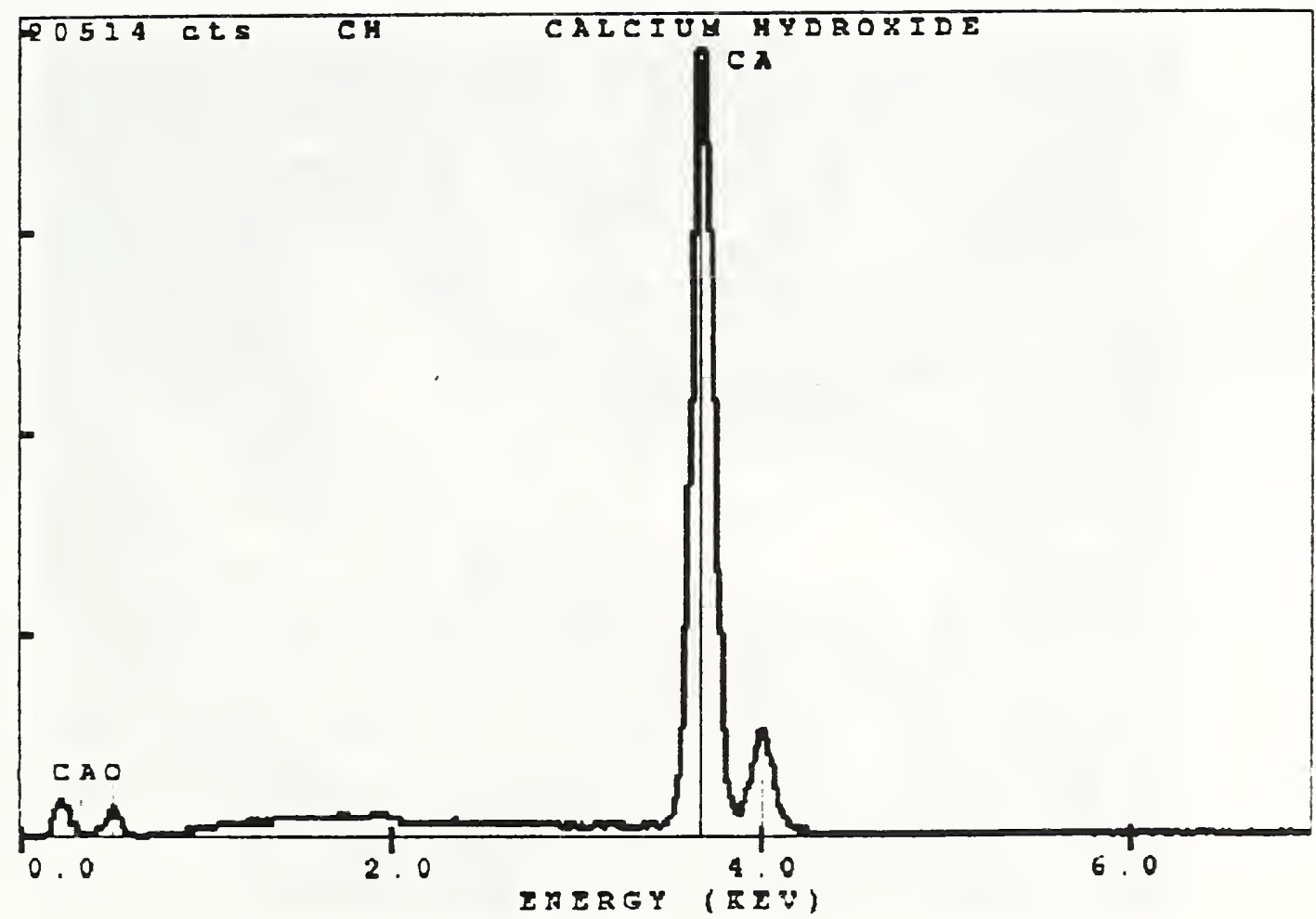

(b)

Figure 4. Secondary electron image (a) of a fresh fracture surface showing calcium hydroxide $(\mathrm{CH})$, calcium-silicate-hydrate $(\mathrm{CSH})$, and void space (V), and (b) energy dispersive X-ray spectrum of calcium hydroxide; peaks indicate the presence of calcium ( $C A$ ) and oxygen (O). 


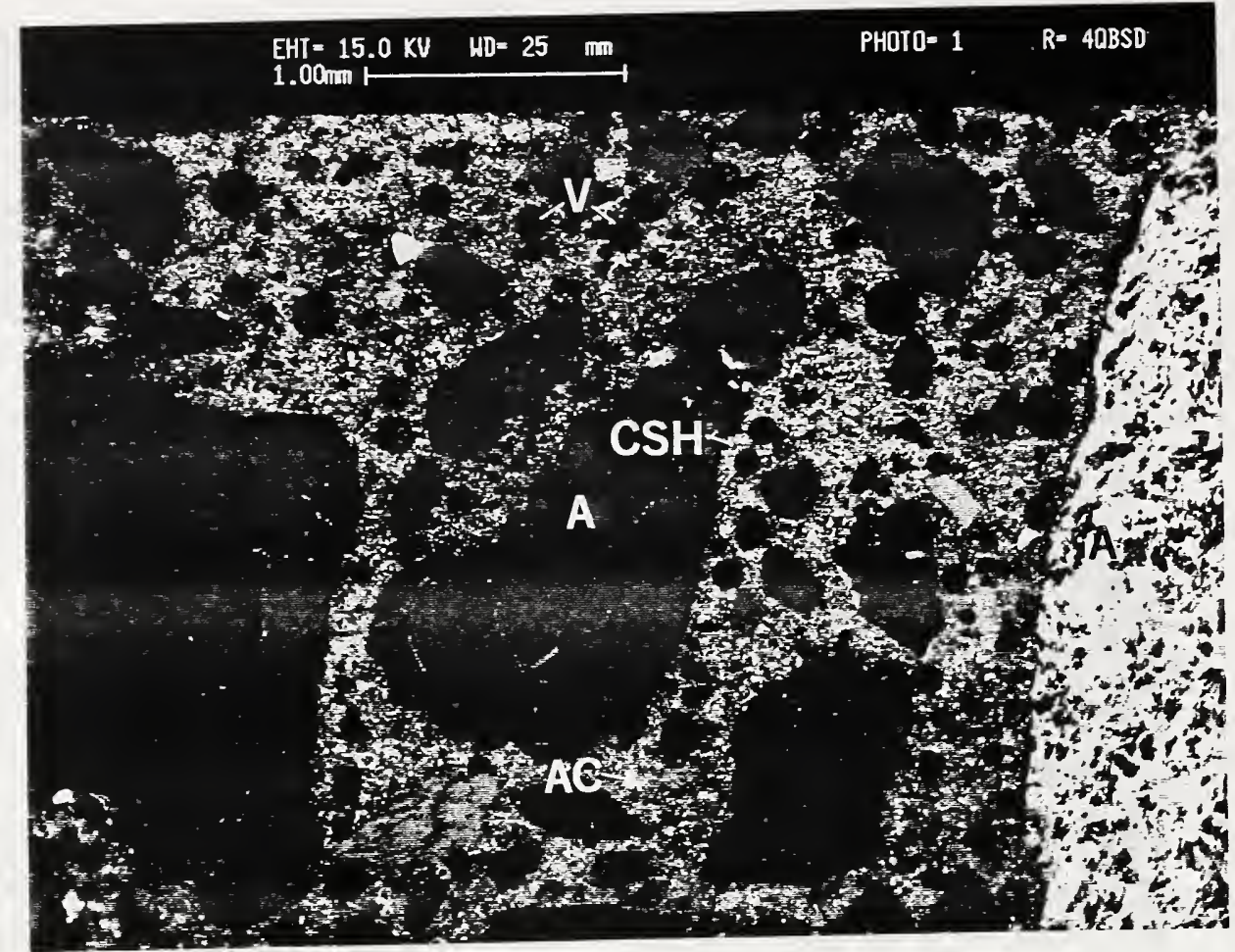

(a)

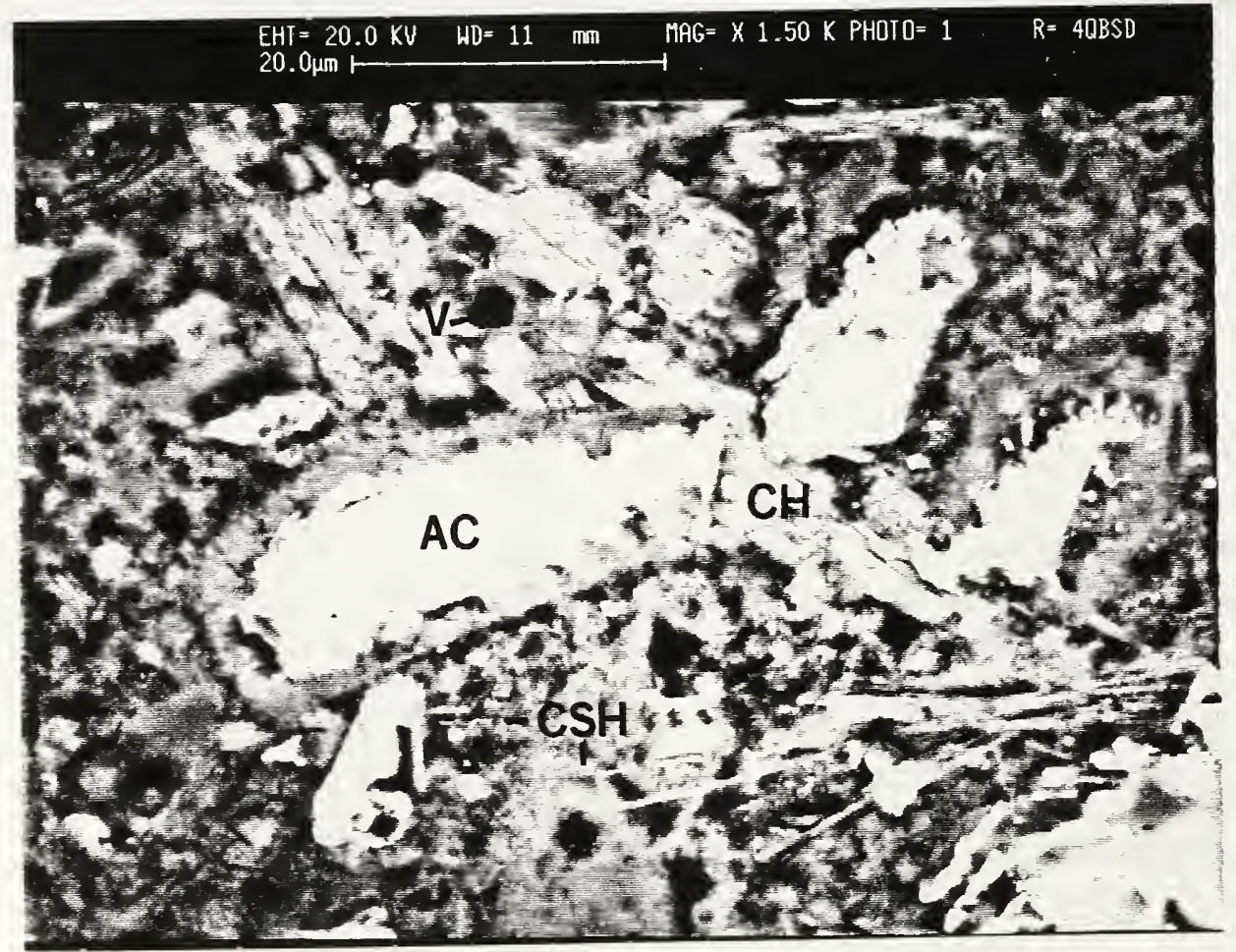

(b)

Figure 5. Backscattered electron images of (a) hardened concrete and (b) hardened cement paste with aggregate (A), anhydrous cement ( $A C)$, calcium silicate hydrate (CSH), calcium hydroxide $(\mathrm{CH})$, and void space (V). 


\subsection{X-Ray Powder Diffraction}

$X$-ray powder diffraction (XRD) is a reliable method of mineral and compound identification. A monochromatic beam of $\mathrm{X}$-rays produced by the diffractometer strikes a finely-powdered sample, is diffracted by atomic planes of the compounds, and is detected and measured by the X-ray detector. Each compound has a unique diffraction pattern and can be identified by measuring the diffraction peak positions and relative intensities. $\mathrm{x}$-ray powder diffraction can be used for phase identification of cement clinker, cement, aggregates, fracture-filling material, efflorescence, and hardened concrete. Table 4 outlines general sample preparation procedures for XRD analysis. The International Center for Diffraction Data (JCPDS) database of powder diffraction patterns can be used for phase identification. Table 5 lists key diffraction peaks and overlaps for most cement phases, while chen [56] provides tables for rapid identification of common aggregate minerals. Figure 6 shows $X-r a y$ powder

diffraction patterns with (a) non-carbonated cement paste and (b), cement paste from a carbonated concrete. The presence of carbonation is clearly shown in figure $6(b)$ by the intense calcite peak. Quantitative analysis is possible but requires standards and calibration mixtures. More information on cement phase identification can be found in Mather [57], Kantro [58,59], TRB Special Report 127 [60], and Taylor [61].

$\mathrm{X}$-ray analysis of hydrated cement is hampered by the poor to noncrystalline nature of the hydrated compounds and by the aggregate. Aggregate can comprise about $70 \%$ of the concrete, masking $\mathrm{X}$-ray evidence of cement by both sample dilution and peak overlap. A procedure for obtaining cement concentrates [62] is to gently fragment the concrete, removing the coarse aggregate and sand with the aid of a stereo microscope and tweezers, and sieving the fines through a 100-mesh screen. Concentrating the cement portion of the concrete by sieving will reduce problems due to the aggregate.

Mather [63] concentrated material for X-ray diffraction by using chemical treatments for the selective removal of some of the concrete constituents. Maleic acid in methanol was used to remove the calcium silicates and calcium oxide. Water soluble phases such as calcium oxide, gypsum, and calcium sulfate hemihydrate can be removed using cold water followed by methanol drying, and removal of calcium sulfates is performed by soaking in a $10 \% \mathrm{NH}_{4} \mathrm{CL}$ solution. 
Table 4. Sample Preparation for X-Ray Powder Diffraction Analysis.

1) Fragment sample with steel mortar and pestle.

2) Pick cement paste using a stereo microscope and tweezers.

3) Powder sample, powder passing a 325-mesh sieve.

4) Carefully pack powder in XRD specimen mount.

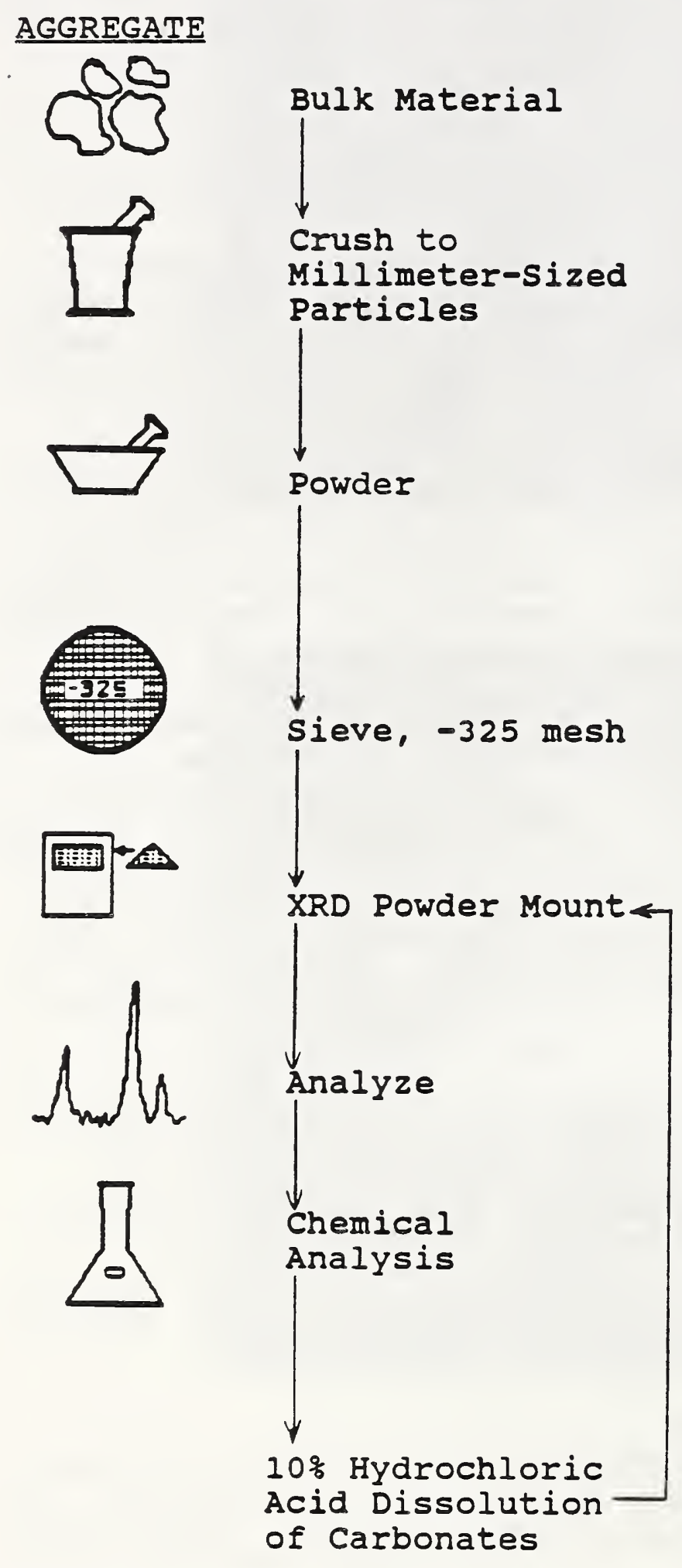

\section{CONCRETE}
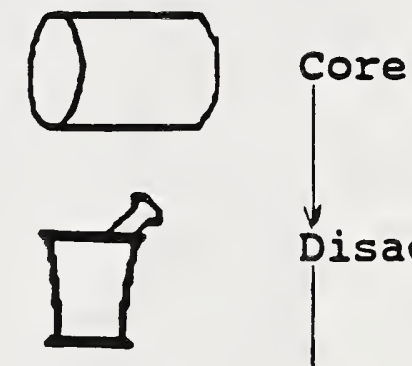

Disaggregate

Millimeter-sized

Particles

$\downarrow$

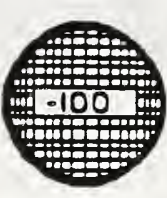

Sieve, -100 mesh. Remove Coarse Aggregate

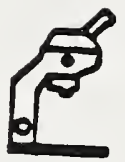

Pick cement concentrates

$\downarrow$

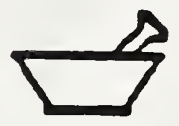

Powder

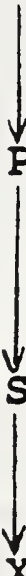

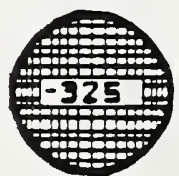

Sieve, -325 Mesh

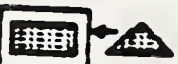

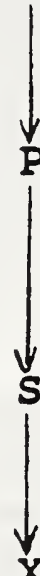

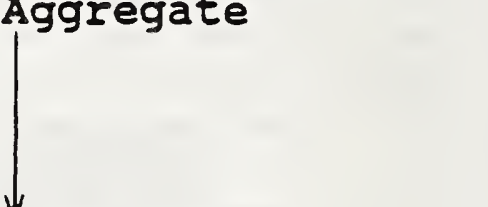

XRD Powder Mount

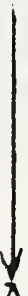

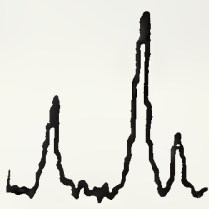

Analyze 
Table 5. Key X-Ray Powder Diffraction Lines for Hydrous and Anhydrous Cement Compounds', from Mather [57]

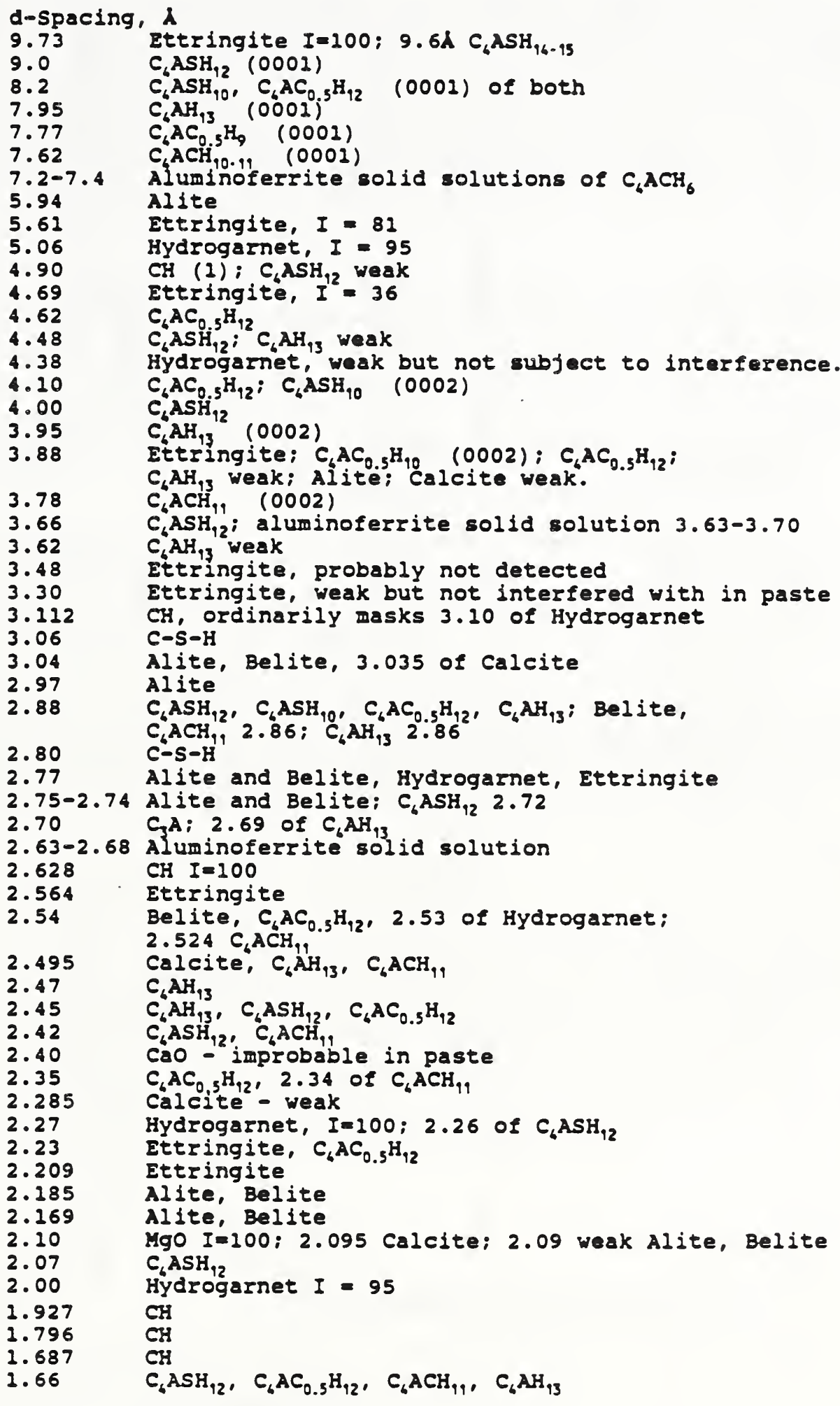

'The following abbreviations, common in chemical formulae of anhydrous and hydrous cement compounds, are used: $\mathrm{C}$ for $\mathrm{CaO}, \mathrm{S}$ for $\mathrm{SiO}_{2}$, A for $\mathrm{Al}_{2} \mathrm{O}_{3}, \mathrm{~F}$ for $\mathrm{Fe}_{2} \mathrm{O}_{3}, \mathrm{M}$ for $\mathrm{MgO}, \mathrm{K}$ for $\mathrm{K}_{2} \mathrm{O}, \mathrm{N}$ for $\mathrm{Na}_{2} \mathrm{O}, \overline{\mathrm{S}}$ for $\mathrm{SO}_{3}, \mathrm{C}$ for $\mathrm{CO}_{2}$, and $\mathrm{H}$ for $\mathrm{H}_{2} \mathrm{O}$. 


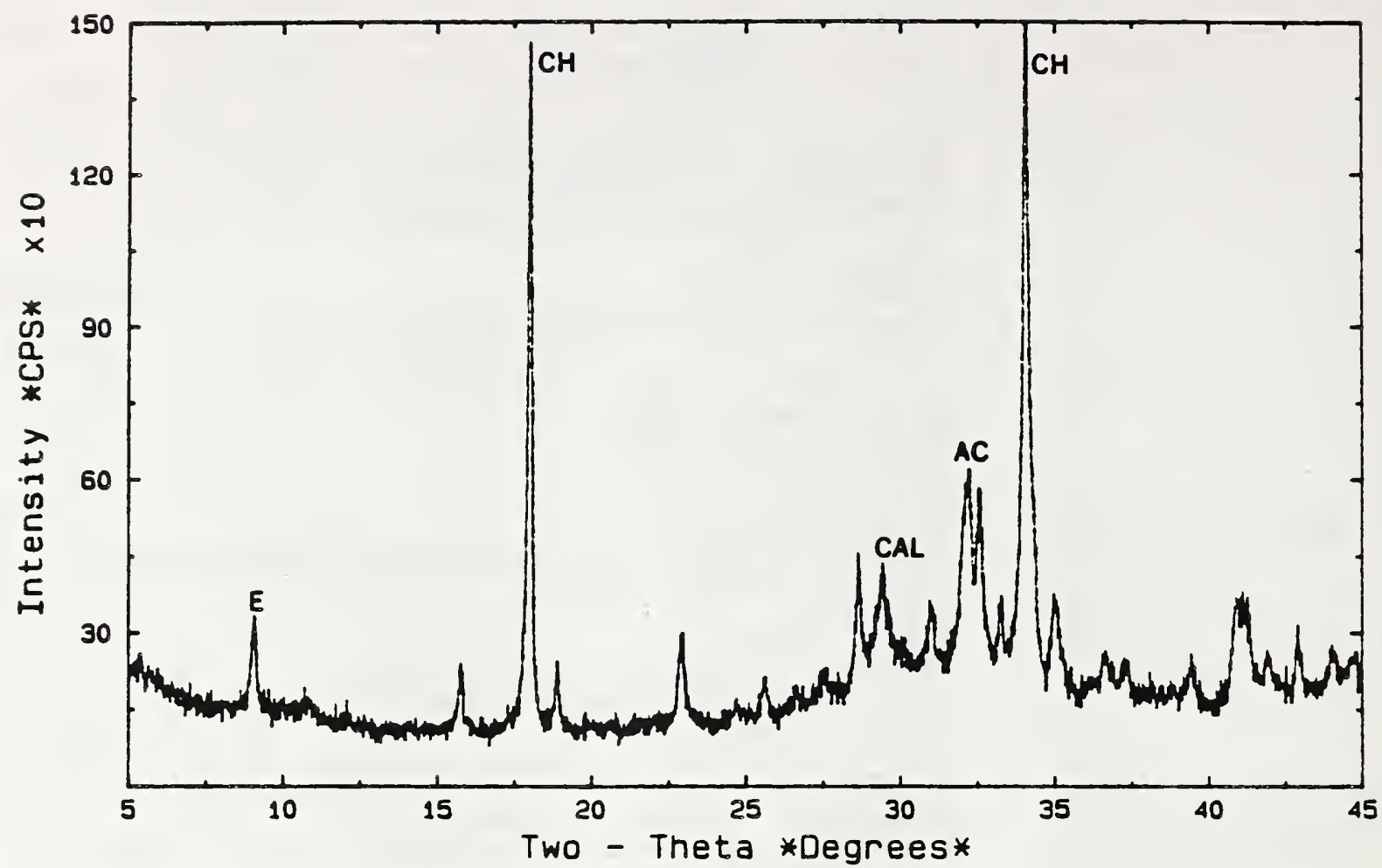

(a)

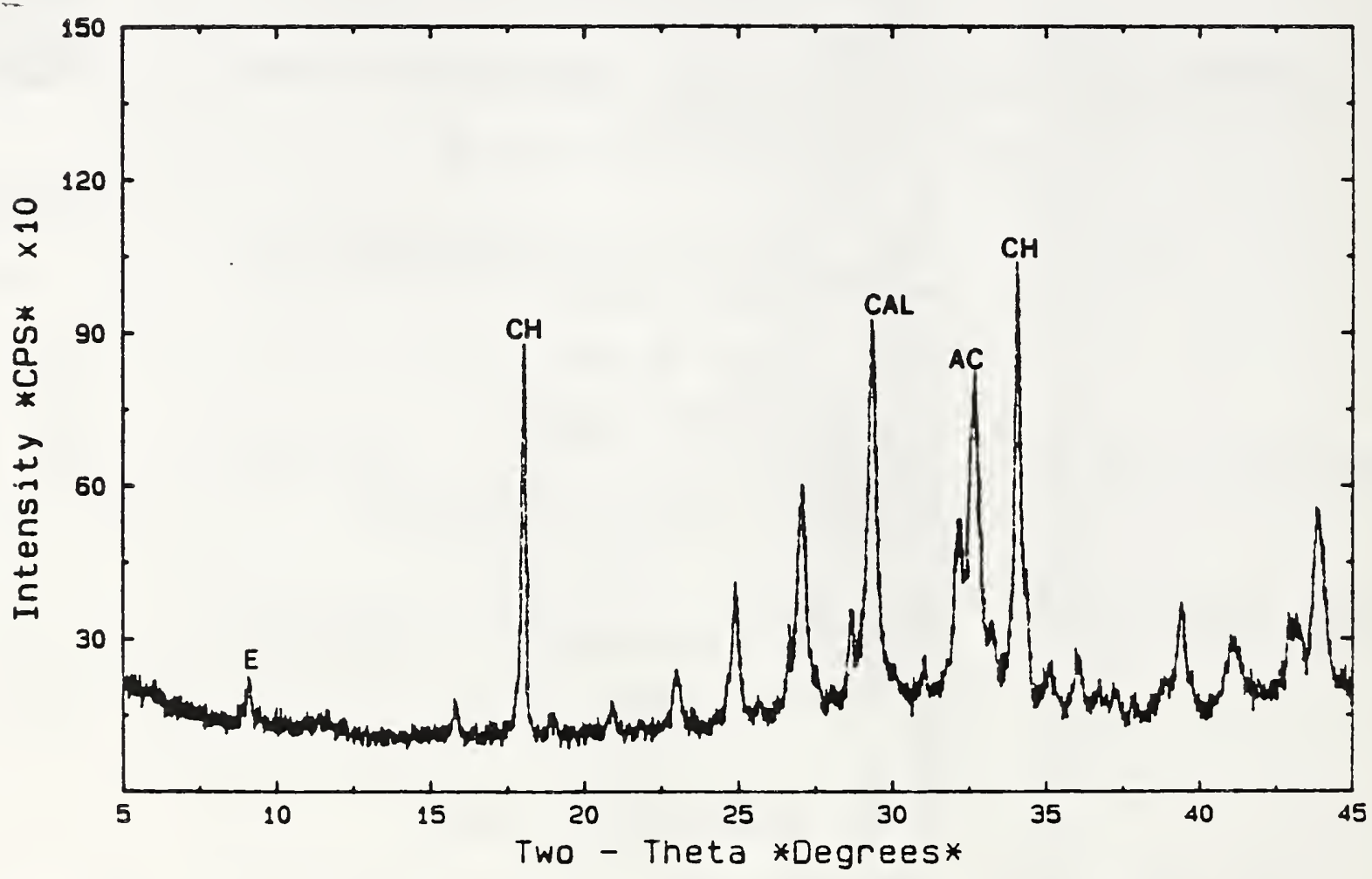

(b)

Figure 6. X-ray powder diffraction patterns of (a) hydrated cement paste and (b) carbonated paste, with calcium hydroxide ( $\mathrm{CH}$ ), ettringite (E), calcite (CAL), and anhydrous cement (AC). 


\subsection{Other Methods of Analysis}

Thermal techniques are also used for cement phase identification $[64,65]$. Differential thermal analysis monitors the endothermic and exothermic reactions that occur when the hydrated cement paste is heated at a constant rate and, similar to $\mathrm{x}$-ray powder diffraction, uses these patterns as fingerprints of the phases. Difficulties encountered are peak overlaps from different phases, low sensitivity, and lack of a standard sample preparation method for drying prior to the analysis.

Bungey [14] reviewed chemical test methods from both ASTM and British standards for cement content, total original water content, cement and mineral admixture type identification, aggregate type and grading, sulfate and chloride determination, alkali content, and carbonation tests. Hime et al. [65] used infrared analysis for the identification of organic admixtures in cement and hardened concrete.

In his examination of direct physical methods for surface, bulk and chemical characterization of microstructures, Pratt [66] stated that the method used for microstructural analysis should fit the scale of information required by the problem. Microscopical methods provide information on the paste microstructure including the interrelationships of the compounds comprising the paste. Indirect methods deriving information over a relatively larger area or bulk of the material include X-ray diffraction, electrical resistivity, thermogravimetry, calorimetry, and various spectroscopic techniques.

\subsection{PHYSICAI TESTING IN THE LABORATORY}

Physical testing of hardened concrete in the laboratory is discussed by Brink [17]. In addition to a discussion of tests of porosity and permeability, Brink presents tests on cored or cut sections that include compressive strength [67]; freeze-thaw resistance [68,69]; length change of concrete [70]; exposure of concrete to sulfate solutions, high humidity and temperature conditions; and measurement of specific gravity, absorption and voids [71]. 


\subsection{SUMMARY}

Field evaluation and testing of concrete structures is important for monitoring the condition of the structure throughout its service life. Field and laboratory evaluation can also be used to determine the condition of concrete, location, extent, and causes of degradation of concrete, and the identification and location of substandard concrete. Information from the evaluation can be useful in developing an improved understanding of the relationships between performance and exposure conditions.

A wide variety of useful test procedures and guidelines for inspection and evaluation are available from such groups as the American Concrete Institute (ACI), the American Society for Testing and Materials (ASTM) and the American Association of State Highway Transportation officials (AASHTO).

Some of the tools available in concrete laboratories for the characterization of concrete include optical microscopes, electron microscopes with $\mathrm{x}$-ray analytical capabilities, $\mathrm{x}$-ray diffractometers, thermal analysis systems, chemical and strength testing capabilities, and not least of all, the observation and experience of the concrete petrographer.

The scanning electron microscope is becoming an important analytical tool for the concrete petrographer. Quantitative petrographic data can be obtained by combining imaging capabilities of surface topography, phase distribution, and elemental distribution with chemical analysis, with image processing and analysis.

\subsection{ACKNOWLEDGEMENTS}

The financial support of NIST and the suggestions of Dr. James Clifton of the Building Materials Division of NIST and the comments and suggestions of the reviewers Dr. Nicholas Carino, Dr. Larry Knab, Ken Snyder, and Marsha McBurney are gratefully acknowledged. 


\section{0 REFERENCES}

1. ASTM C 823-83, "Standard Practice for Examination and Sampling of Hardened Concrete in Constructions," ASTM, Philadelphia, PA., 1990.

2. Mather, K., "Petrographic Examination," In: Significance of Tests and Properties of Concrete and concrete-Making Materials, ASTM Special Technical Publication 169B, pp. 132-145, 1978.

3. ACI Committee 201, "Guide for Making a condition survey of Concrete in Service," ACI 201.1R-68, American Concrete Institute, Detroit, 1990, 14 pp., ACI Manual of Concrete Practice, Part 1.

4. ACI Committee 207, "Practices for Evaluation of Concrete in Existing Massive Structures for Service Conditions," ACI 207.3R-79, American Concrete Institute, Detroit, 1990, 15 pp., ACI Manual of Concrete Practice, Part 1.

5. Mielenz, R.C., "Petrography Applied to Portland Cement Concrete," Reviews in Engineering Geology, Vol. 1, 1962, 38 pp.

6. Portland Cement Association, Concrete Inspection Procedures, John Wiley and Sons, New York, 1975, 146 pp.

7. ACI Committee 224, "Causes, Evaluation, and Repair of Cracks in Concrete structures," ACI 224.1R-89, American Concrete Institute, Detroit, 1990, 20 pp., ACI Manual of Concrete Practice, Part 3.

8. ACI Committee 309, "Identification and Control of ConsolidationRelated Surface Defects in Formed Concrete," ACI 309.2R-82, American Concrete Institute, Detroit, 1990, 11 pp., ACI Manual of Concrete Practice, Part 2 .

9. Mindess, S., and Young, J.F., Concrete, Prentice-Hall, Inc., Englewood Cliffs, N.J., 1981, 671 pp.

10. ACI Committee 201, "Guide for Making a Condition survey of Concrete Pavements," ACI 201.3R-86, American Concrete Institute, Detroit, 1990, 23 pp., ACI Manual of Concrete Practice, part 1.

11. U.K. Concrete Society Technical Report 22, "Non-structural Cracks in Concrete," Report of a concrete society Working Party, December, 1982. 38p.

12. Strategic Highway Research Program Report SHRP-LTPP/FR-90-011, "Distress Identification Manual for the Long-Term Pavement Performance Studies," Transportation Research Board, National Research Council, Washington, D.C., October, 1990, 73 pp.

13. Kaetzel, L.J., J.R. Clifton, and D.P. Bentz, "Integrating Knowledge for the Identification of Cracks in concrete Using an Expert System Shell and Extensions," NISTIR 89-4206, 28 pp., 1989. 
14. Bungey, J.H., The Testing of Concrete structures, Hall, Inc., New York, 1989, 228 pp.

Chapman and

15. Mathey, R.G., and J.R. Clifton, "Review of Nondestructive

Evaluation Methods Applicable to Construction Materials and

Structures," NBS Technical Note 1247, Washington, D.C., 1987, 162

pp.

16. Mather, K, "Preservation Technology: Evaluating Concrete in structures," Concrete International, October, 1985, pp. 33-41.

17. Brink, R.H., "Physical Tests for Investigating Performance of Concrete," In: Highway Research Board Special Report 106 , Observations of the performance of concrete in Service, Washington, D.C., 1970, pp. 17-28.

18. Malhotra, V.M. and N.J. Carino, Handbook on Nondestructive Testing of Concrete, CRC Press, Boca Raton, 1991, 343 pp.

19. ASTM C 805-85, "Standard Test Method for Rebound Number of Hardened Concrete," ASTM, Philadelphia, PA., 1990.

20. ASTM C 597-83, "Standard Test Method for Pulse Velocity through Concrete," ASTM, Philadelphia, PA., 1990.

21. ASTM C 803-90, "Standard Test Method for Penetration Resistance of Hardened Concrete," ASTM, Philadelphia, PA., 1990.

22. ASTM C 900-87, "Standard Test Method for Pullout strength of Hardened Concrete," ASTM, Philadelphia, PA., 1990.

23. RILEM Recommendation CPC-18, "Measurement of Hardened Concrete Carbonation Depth," Materials and Structures, Vol. 21, No. 126, pp. $453-455,1988$.

24. Parrott, L.J., "Damage Caused by Carbonation of Reinforced Concrete," Materials and Structures, 23, pp. 230-234, 1990.

25. James Instrument company, CL 1000 Chloride Test system data sheet, Chicago, Illinois, 1990.

26. Schupack, M., "Fast Field Test for Chloride Ion," concrete Construction, July, 1989, pp. 644-647.

27. Jang, J.W. and I. Iwasaki, "Visualization of Chloride Distribution in Concrete," Transportation Research Board 70 th Annual Meeting Preprint No. 910156, January 13-17, 1991.

28. AASHTO T-260-84, "Standard Method of Sampling and Testing for Total Chloride Ion in concrete and Concrete Raw Materials," In: Standard Specifications for Transportation Materials and Methods of Sampling and Testing, 14th edition, Part 2, American Association of State Highway Transportation Officials, 1986. 
29. ASTM C 876-87, "Standard Test Method for Half-Cell Potentials of Uncoated Reinforcing Steel in Concrete," ASTM, Philadelphia, PA, 1990 .

30. Natesaiyer, K. and K.C. Hover, "Insitu Identification of ASR Reaction Products in Concrete," Cement and Concrete Research, Vol. 18, pp. 455-463, 1988 .

31. Natesaiyer, $\mathrm{K}$ and K.C. Hover, "Further Study of an In-Situ Identification Method for Alkali-Silica Reaction Products in Concrete," Cement and Concrete Research, Vol. 19, pp. 770-778, 1989.

32. Natesaiyer, K, Stark, D, and K.C. Hover, "Gel Fluorescence Reveals Reaction Product Traces," Concrete International, Vol. 13, No. 1, pp. 25-28, 1991 .

33. Poole, A.B., Mclachlan, A., and D.J. Ellis, "A Simple staining Technique for the Identification of Alkali-Silica Gel in concrete and Aggregate," Cement and Concrete Research, Vol. 18, pp. 116-120, 1988 .

34. Stark, D., Handbook for the Identification of Alkali-Silica Reactivity in Highway Structures, Strategic Highway Research Program SHRP-C/FR-91-101, Transportation Research Board, Washington, D.C., 49 pp., 1991.

35. ASTM C 42-87, "Standard Test Method for Obtaining and Testing Drilled Cores and Sawed Beams of Concrete," ASTM, Philadelphia, PA., 1990.

36. Concrete Manual, 8th ed., U.S. Bureau of Reclamation, (1975).

37. ASTM C 856-83, "Standard Practice for Petrographic Examination of Hardened Concrete," ASTM, Philadelphia, PA., 1990.

38. ASTM C 457-82a, "Standard Practice for Microscopical Determination of Air-Void Content and Parameters of the Air-Void System in Hardened Concrete," ASTM, Philadelphia, PA., 1990.

39. ASTM C 294-86, "Standard Descriptive Nomenclature for Constituents of Natural Mineral Aggregates," ASTM, Philadelphia, PA. , 1990 .

40. ASTM C 295-85, "Standard Practice for Petrographic Examination of Aggregates for Concrete," ASTM, Philadelphia, PA., 1990.

41. Brown, L.S. "Petrography of Cement and Concrete." Journal of the P.C.A. Research and Development laboratories, Vol. 1, No. 3, Sept. 1959, pp. 23-34.

42. Campbell, D.H., "Application of the Microscope in the Concrete Industry," Proceedings of the Third International conference on Cement Microscopy, pp. 286-297, Duncanville, Tx. 1981. 
43. Campbel1, D.H., Microscopical Examination and Interpretation of Portland cement and Clinker, Portland Cement Association, 128 pp., 1986.

44. Erlin B., "Methods Used in Petrographic Studies of Concrete," Analytical Techniques for Hydraulic cements and concrete, ASTM STP 395, ASTM, Philadelphia, PA, 1965, pp. 3-17.

45. Erlin B., "Analytical Techniques," In: Highway Research Board Special Report 106, observations of the Performance of concrete in Service, Washington, D.C., 1970, pp. 29-37.

46. Mielenz, R.C., "Diagnosing Concrete Failures," Stanton Walker Lecture Series on the Material Sciences $47 \mathrm{p}$. University of Maryland, College Park, Nov. 18, 1964.

47. Idorn, G.M., Durability of Concrete structures in Denmark, $A$ Study of Field Behaviour and Microscopic Features, Danish Technical Press, Copenhagen, 1967, 208 pp.

48. Dolar-Mantuani, L., Petrography of Concrete and Concrete Aggregates, Noyes Publications, Park Ridge, NJ, 1983, 345 pp.

49. American Society for Testing and Materials STP 1061, Petrography Applied to concrete and concrete Aggregates, B. Erlin and D. Stark, Eds., ASTM, Philadelphia, PA, 1990, 208 pp.

50. Walker, H., "Examination of Portland cement Concrete by Fluorescent Light Microscopy," In: Proceedings of the Third International Conference on Cement Microscopy, pp. 257-278, Duncanville: ICMA (1981).

51. Scrivener, K.L., "Quantification of Microstructure," In: Advances in Cement Manufacture and Use, E. Gartner, Ed. , 1988, pp. 3-13.

52. Uchikawa, H., "Similarities and Discrepancies of Hardened Cement Paste, Mortar and Concrete from the standpoints of composition and Structure," Journal of Research, Onoda Cement Company, Vol. 40, No. $119,1988,24$ pp.

53. Struble, L.J., and P.E. Stutzman, "Epoxy Impregnation of Hardened Cement for Microstructural Characterization," Journal of Materials Science Letters, 8, (1989), pp. 632-634.

54. Stutzman, P.E., "Serial Sectioning of Hardened Cement Paste for Scanning Electron Microscopy," NISTIR 90-4235, 1990, 23 pp.

55. Goldstein, J.I., Newbury, D.E., Echlin, P., Joy, D.C., Fiori, C., and Lifshin, E., Scanning Electron Microscopy and X-Ray Microanalysis, Plenum Press, New York, 1984, 673 pp. 
56. Chen, P.Y., "Table of Key Lines in X-Ray Diffraction Patterns of Minerals in Clays and Associated Rocks," Department of Natural Resources Geological Survey Occasional Paper 21, 1977, 67 pp.

57. Mather, K., "Examination of Cement Pastes, Hydrated Phases, and Synthetic Products by X-Ray Diffraction," In: Transportation

Research Circular 176, Evaluation of Methods of Identifying Phases of Cement Paste, pp. 9-30, 1976 .

58. Kantro, D., "The Quantitative Determination of Alite and Belite Residues in Partly Hydrated Cement Pastes," In: Transportation Research Circular 176, Evaluation of Methods of Identifying Phases of Cement Paste, pp. 4-9, 1976.

59. Kantro, D.L., Copeland, L.E., and E.R. Anderson, "An X-RaY Diffraction Investigation of Hydrated Portland Cement Pastes," Portland Cement Association Bulletin 128, 1960, pp. 1020, 1035.

60. Highway Research Board, "Guide to Compounds of Interest in Cement and Concrete Research," Special Report 127, 1972, 53 pp.

61. Taylor, H.F.W., Cement Chemistry, Academic Press, San Diego, 475 pp., 1990.

62. Mather, K., Luke, W.I., and Mather, B., 1963, "Aggregate Investigations, Milford Dam, Kansas, Examination of Cores From Concrete Structures," U.S. Army Engineer Waterways Experiment Station Technical Report 6-629, 47 pp.

63. Mather, K., "X-ray diffraction examination of the phases in expansive cements," Advances in X-Ray Analysis, 20, 1974, pp. 41-52.

64. Kalousek, G.L. and K.T. Green, "Differential Thermal Analysis Tests of Hydrated Cements and Individual Hydrates," In:

Transportation Research Circular 176, Evaluation of Methods of Identifying Phases of Cement Paste, pp. 30-41, 1976.

65. Hime, W.G., W.F. Mivelaz, and J.D. Connolly, "Use of Infrared Spectrophotometry for the Detection and Identification of Organic Additions in Cement and Admixtures in Hardened Concrete," Analytical Techniques for Hydraulic cements and concrete, ASTM STP 395, ASTM, Philadelphia, PA, 1965, pp. 18-29.

66. Pratt, P.L., "Physical Methods for the Identification of Microstructures," Materials and Structures, Vol. 21, No. 122, pp. $106-117,1988$.

67. ASTM C 39-86, "Standard Test Method for Compressive Strength of Cylindrical Concrete Specimens," ASTM, Philadelphia, PA., 1990

68. ASTM C 666-84, "Standard Test Method for Resistance of Concrete to Rapid Freezing and Thawing," ASTM, Philadelphia, PA., 1990. 
69. ASTM C 671-86, "Standard Test Method for Critical Dilation of Concrete specimens Subjected to Freezing," ASTM, Philadelphia, PA., 1990 .

70. ASTM C 341-89, "Standard Test Method for Length Change of Drilled or Sawed Specimens of Hydraulic-Cement Mortar and concrete," ASTM, Philadelphia, PA., 1990.

71. ASTM C 642-90, "Standard Test Method for Specific Gravity, Absorption, and Voids in Hardened Concrete," ASTM, Philadelphia, PA. , 1990. 
NIST-114A

(REV. 3-90)
U.S. DEPARTMENT OF COMMERCE NATIONAL INSTITUTE OF STANDARDS AND TECHNOLOGY

\section{BIBLIOGRAPHIC DATA SHEET}

1. PUBUCATION OR REPOAT NUMBER

NISTIR 4516

2 PERFORMING ORGANIZATION REPORT NUMBER

3. PUBUCATIONDATE

JANUARY 1991

4. TITLE AND SUBTTIUE

Characterization of Field Concrete

5. AUTHOR(S)

Paul E. Stutzman

6. PERFORMING ORQANIZATION (IF JOINT OR OTHER THAN MIST, SEE INSTRUCTIONS)

U.S. DEPARTMENT OF COMMERCE

MATIONAL INSTTTUTE OF STANDARDS AND TECHMOLOQY

GATHERSBURG, MD 20890

7. CONTRACT/GRANT MUMBER

8. TYPE OF REPORT ANO PERIOD COVERED

9. SPONSORINO ORGAMIZATION MAME AND COMPLETE ADDRESS (STREET, GTY, STATE, ZP)

11. ABSTRACT (A 200-WORD OR LESS FACTUAL SUMMARY OF MOST SIOMIFCANT INFORMATION. IF DOCUMENT INCLUDES A SIGNIFICANT BIBLOGRAPHY OA LTERATURE SURVEY, METTON TT HERE)

Field inspection and laboratory analysis of concrete and concrete structures are necessary for condition evaluation, determination of the need and extent of repairs, and for the prediction of concrete service life. A detailed evaluation includes field inspection, field testing, sampling, and laboratory analyses and also involves the description of the structure, concrete, and aggregates. Field inspection for overall structure condition includes the identification and description of surface defects, cracks, and cracking patterns. Field testing determines relative concrete quality and location of degraded concrete, and provides guidance in developing a sampling plan. Laboratory analyses provide detailed information on the microstructure, phase composition, chemical composition, and strength of the concrete.

This report discusses the inspection and evaluation of field concrete, the application of field tests for determining concrete condition, sampling concrete for analyses, and laboratory testing for the characterization and evaluation of concrete microstructure.

12. KEY WORDS (6 TO 12 ENTRIES: ALPHABETICAL ORDER; CAPITAUZE OHLY PAOPER MAMES; AND SEPARATE KEY WORDS BY SEMICOLONE)

Key Words: characterization, concrete, evaluation, field survey, field testing, laboratory analysis, microscopy, petrography -.... - - - ...., 

